\title{
TEKLA Z WODZICKICH MAŁACHOWSKA JAKO PROTEKTORKA TOWARZYSTWA DOBROCZYNNOŚCI W KRAKOWIE. PRZYCZYNEK DO BIOGRAFII
}

\begin{abstract}
Abstrakt: Bohaterką tekstu jest Tekla z Wodzickich Małachowska (1764-1829), córka Eliasza, starosty krakowskiego, i Ludwiki z Wielopolskich. Tekla była drugą żoną Piotra Małachowskiego (ok. 1730-1799), wojewody krakowskiego. Po śmierci męża zamieszkała w Stopnicy pod Krakowem. Do życia publicznego powróciła w okresie Księstwa Warszawskiego. Wtedy przeniosła się do Krakowa. Włączyła się w działania przy organizacji Towarzystwa Dobroczynności. W lutym 1817 roku została pierwszą prezeską Towarzystwa. Troszczyła się o swoich podopiecznych, organizowała koncerty charytatywne, bale, na których zbierała pieniądze dla Towarzystwa. Walory osobiste i działalność społeczno-charytatywna zyskały jej powszechny szacunek. Do grona przyjaciół zaliczali ją nie tylko przedstawiciele rodów magnackich osiadłych w Krakowie, ale także czołowi intelektualiści epoki, m.in. Jan Śniadecki. Testamentem zapisała 12 tys. złp na edukację dzieci w Niedźwiedziu. Zmarła 22 grudnia 1929 roku, pochowana obok męża w Niedźwiedziu. Towarzystwo było bardzo wdzięczne protektorce za opiekę, dlatego 11 lutego 1821 roku uchwaliło, aby malowane na blasze portrety jej i Stanisława Mieroszewskiego zawiesić w kaplicy ubogich na Wawelu. Portrety te, odbite na miedzi, później rozpowszechnione zostały wśród członków towarzystwa. Po śmierci Małachowskiej 16 stycznia 1830 roku w kaplicy ubogich odprawiono żałobne nabożeństwo za jej duszę. Wygłoszone na nim wtedy kazanie ku czci Tekli Małachowskiej kilka lat później wpisano do pamiątkowej Księgi zmarłych dobroczyńców Towarzystwa.
\end{abstract}

Słowa kluczowe: Tekla z Wodzickich Małachowska, Towarzystwo Dobroczynności w Krakowie, filantropia

Na początku XIX wieku na ziemiach należących do roku 1772 do Rzeczypospolitej zaczęły powstawać towarzystwa dobroczynności, m.in. w Warszawie, Wilnie, Lublinie, Lwowie, Mińsku, Kaliszu, Poznaniu. W tym duchu w roku 1816 
z inicjatywy przewodniczącego Senatu Rządzącego Wolnego, Niepodległego i Ściśle Neutralnego Miasta Krakowa i jego Okręgu hrabiego Stanisława Wodzickiego ${ }^{1}$, przy współudziale Stanisława Mieroszewskiego ${ }^{2}$, podjęto działania w celu założenia domu opieki albo towarzystwa dobroczynności w Krakowie 3 . Przygotowano projekt i napisano statut Towarzystwa. 16 listopada 1816 roku wydano odezwę do mieszkańców Krakowa, w której przedstawiono zasady działania i cele towarzystwa. Wystosowano w niej również prośbę o wsparcie inicjatywy i datki, gdyż jego działalność opierała się tylko na ofiarności członków. W odpowiedzi na apel spływały zewsząd datki w większych i mniejszych sumach stosownie do zamożności i hojności niosących ofiary ${ }^{4}$, zebrano także wiele darów (odzież, pościel, sprzęty, żywność). Dodatkowo Senat uchwalił subwencję na działalność Towarzystwa i wyraził zgodę na pobieranie na cele dobroczynne opłat od widowisk

${ }^{1}$ Stanisław Wodzicki (1764-1843) - pamiętnikarz, poeta, botanik, polityk konserwatywny, przywódca krakowskiego stronnictwa arystokratycznego, w latach 1818-1831 prezes Senatu Rządzącego Wolnego Miasta Krakowa, senator-wojewoda Królestwa Polskiego, zob. Wodzicki Stanisław, [w:] Bibliografia literatury polskiej. Nowy Korbut, t. 6, cz. 1: Oświecenie, Warszawa 1970, s. 439-444; [S. Wodzicki], Pamiętniki [...], Kraków 1888.

2 Stanisław Mieroszewski (1756-1824) - poseł na Sejm Czteroletni i do Izby Reprezentantów Wolnego Miasta Krakowa, ordynat dóbr mysłowickich. Po upadku powstania kościuszkowskiego wyjechał na wieś; wznowił działalność polityczną i społeczną w okresie Księstwa Warszawskiego na terenie Wolnego Miasta Krakowa. W 1816 r. był członkiem honorowym Towarzystwa Naukowego Krakowskiego. Po utworzeniu Towarzystwa Dobroczynności w Krakowie był jego pierwszym prezesem, wspierał je finansowo, ustanowił m.in. legat 1000 złp dla sierot wychowywanych pod opieką Towarzystwa, a kierowanych do nauki rzemiosł. Do Towarzystwa werbował możne osoby, także spoza granic kraju, zob. J. Bieniarzówna, Mieroszewski (Miroszewski, Mieroszowski) Stanisław h. Ślepowron, [w:] Polski Słownik Biograficzny [dalej: PSB], t. 21, red. nacz. E. Rostworowski, Kraków-Wrocław 1976, s. 2-3; S. i S. Mieroszewscy, Wspomnienia lat ubiegłych, przygot. do dr. M. i H. Baryczowie, Kraków 1964.

${ }^{3}$ Mimo olbrzymiej bazy źródłowej, zgromadzonej m.in. w Archiwum Państwowym w Krakowie, oddział przy ul. Siennej, w Archiwum Uniwersytetu Jagiellońskiego i Bibliotece Jagiellońskiej oraz dokumentów przechowywanych w archiwach kościelnych dotychczas nie powstało pełne opracowanie dziejów Towarzystwa Dobroczynności w Krakowie. Dysponujemy tylko dziewiętnastowiecznym szkicem Józefa Teodora Głębockiego i kilkoma przyczynkami, zob. J.T. Głębocki, Zakłady ku ulżeniu cierpieniom bliźnich obecnie w Krakowie istniejące z krótka wzmianką o dawniejszych, a dziś nie istniejących tego rodzaju, Kraków 1852; E. Barnaś, Powstanie i pierwsze lata działalności Krakowskiego Towarzystwa Dobroczynności (1816-1820), „Zeszyty Naukowe WSP w Rzeszowie. Pedagogika i Psychologia”, 1997, z. 3, s. 87-99; J. Bąk, Opieka społeczna nad sierotami w Krakowskim Towarzystwie Dobroczynności w latach 1816-1916, „Rocznik Krakowski” 1975, t. XLVI, s. 99-112; J. Bek, Opieka nad sierotami, Lwów 1916; L. Dydusiak, Zagadnienie żebractwa w Polsce, Borysław 1938; T. Kargol, Rola ziemianek w powstaniu oraz działalności instytucji opieki społecznej i dobroczynności publicznej Lublina, Warszawy i Krakowa, [w:] Ziemiaństwo na Lubelszczyźnie III. Panie z dworów i pałaców, red. H. Łaszkiewicz, Lublin 2007, t. 2, s. 167-184; Z. Krzyżanowska, Dobroczynność w Krakowie, Kraków 1931.

${ }^{4}$ [S. Wodzicki], Pamiętniki, s. 66. 
publicznych ${ }^{5}$. Środki niezbędne do działalności Towarzystwa zgromadzono tak szybko, że już 9 grudnia 1816 roku mogło nastąpić jego utworzenie, w wyniku połączenia funduszy dwunastu małych i biednych szpitali krakowskich ${ }^{6}$, oraz otwarcie na Wawelu przytułku dającego schronienie „starcom i kalekom niemogącym zarobić na kawałek chleba"' . W roku 1817 wpłynęły również znaczne kwoty z dworów trzech krajów zaborczych. Franciszek I darował 4200 złp, Aleksander I - 6666 złp 20 gr, Fryderyk Wilhelm III - 3672 złp. Do powiększenia funduszy Towarzystwa przyczyniali się członkowie władz miasta - m.in. ks. Antoni Bystrzonowski ${ }^{8}$, senator Walenty Bartsch ${ }^{9}$ - a także mieszkający w Krakowie przedstawiciele bogatych rodów magnackich, m.in. Potockich, Mieroszewskich, Wodzickich, Michałowskich i Badenich.

Towarzystwo zapoczątkowało systematyczną opiekę społeczną, wpływając przez cały XIX wiek i początki XX wieku na sprawy dobroczynności publicznej w Krakowie ${ }^{10}$. Za swoje główne zadanie przyjęło opiekę nad biednymi, których liczba w kraju wyniszczonym wojnami przybierała zastraszające rozmiary ${ }^{11}$. Troską otaczano przede wszystkim dorosłych, w mniejszym zaś zakresie dzieci ${ }^{12}$. Siedzibę

${ }^{5}$ J.T. Głębocki, dz. cyt., s. 99; M. Gajda, Krakowskie Towarzystwo Dobroczynności w zbiorach Biblioteki Jagiellońskiej, „Biuletyn Biblioteki Jagiellońskiej” 1988, 38, s. 143.

${ }^{6}$ P.P. Gach, Sieć szpitali w diecezji krakowskiej w połowie XVIII wieku, Lublin 1973.

7 [S. Wodzicki], Pamiętniki, s. 66.

8 Antoni Onufry Bystrzonowski (1769-1848) - ksiądz, po studiach na Uniwersytecie Krakowskim przygotowywał się do stanu duchownego w Kielcach i Warszawie, święcenia przyjął w 1793 r., w roku 1815, po ogłoszeniu Wolnego Miasta Krakowa, mianowany przez Komisję Organizacyjną senatorem dożywotnim, urząd ten sprawował do końca istnienia Rzeczypospolitej Krakowskiej. Był ostatni opatem w Mogile. Należał do wszystkich towarzystw humanitarnych w Krakowie, zob. A. Bystrzonowski, Bystrzonowski Antoni Onufry h. Starykoń, [w:] PSB, t. 3, red. W. Konopczyński, Kraków 1937, s. 173-174.

${ }^{9}$ Walenty Bartsch (1748-1823) - członek Komisji Organizacyjnej i senator dożywotni Wolnego Miasta Krakowa, w 1773 roku został syndykiem miasta Krakowa, od 1774 roku radnym, delegowanym wiele razy w sprawie miasta do króla i rządu. W latach 1802-1810 był wiceprezydentem miasta. W 1815 roku wybrany przez komisarzy Trzech Dworów Opiekuńczych Wolnego Miasta Krakowa na członka adiunkta Komisji Organizacyjnej jako reprezentant stanu trzeciego. Był członkiem honorowym Krakowskiego Towarzystwa Nauk, zob. L. Strojek, M. Friedberg, Bartsch Walenty, [w:] PSB, t. 1, red. W. Konopczyński, Kraków 1935, s. 332.

${ }^{10}$ B. Panek pisał, że to druga wojna światowa ostatecznie położyła kres działalności Krakowskiego Towarzystwa Dobroczynności, zob. B. Panek, Krakowskie organizacje charytatywne w latach 1918-1939, Kraków 1986.

${ }^{11}$ [S. Wodzicki], Pamiętniki, s. 66.

${ }^{12} \mathrm{~W}$ latach osiemdziesiątych XIX wieku postanowiono zbudować na Stradomiu dom dla ubogich starców i kalek (ukończony w 1882 roku) oraz osobno dla dzieci (ukończony w 1884 roku). Zob. A. Haratyk, Rozwój opieki nad dziećmi i młodzieżą w Galicji doby autonomicznej, Wrocław 2002; tenże, Udział społeczeństwa galicyjskiego w opiece nad dziećmi ubogimi i osieroconymi (1867-1914), Kraków 2007; K. Górski, Kronika Krakowa. Śmiertelność dzieci w zakładach opiekuńczych, „Opieka nad Dzieckiem” 1931, R. IX, nr i, s. 22-27; A. Haratyk, Udział społeczeństwa krakowskiego w niesieniu 
Towarzystwa stanowiły pomieszczenia na Wawelu, po 1846 r. krakowskie klasztory (m.in. dominikanów, franciszkanów, pijarów) ${ }^{13}$, a następnie ofiarowane przez małżonków Rotarskich (1852) pomieszczenia na Stradomiu.

Na prezesa Towarzystwa powołano biskupa, wówczas krakowskiego, Jana Pawła Woronicza, który formalnie godność tę przyjął i sprawował w latach 1817-1828. Przeznaczył on sporą sumkę na działalność Towarzystwa, obowiązki nie pozwalały mu jednak realnie działać, bo już wówczas częściej przebywał w Warszawie niż w Krakowie ${ }^{14}$, dlatego poprosił o wybór zastępcy. Został nim Stanisław Mieroszewski, który de facto zainicjował działalność Towarzystwa. 7 stycznia 1817 roku, na prośbę biskupa Woronicza, na prezesową dam została wybrana Tekla z Wodzickich Małachowska, która funkcję tę sprawowała do swojej śmierci ${ }^{15} .29$ kwietnia 1821 roku na prośbę Mieroszewskiego na drugą prezesową, aby pomocną była $\mathrm{Ma}$ łachowskiej i z niq się w każdym zdarzeniu znosiła i naradzała [...] i zastępowała $w$ czasie jej nieobecnościc ${ }^{16}$, wybrano Elżbietę Sztunerową ${ }^{17}$

O Tekli Małachowskiej ani za życia, ani po śmierci nie pisano wiele. Wspominali ją tylko w swoich listach i pamiętnikach najbliżsi członkowie rodziny i współpracownicy ${ }^{18}$. O pamięć o niej zadbali bowiem członkowie Towarzystwa Dobroczynności w Krakowie, którzy jeszcze za jej życia, 11 lutego 1821 roku, uchwalili, aby dla zawdzięczenia gorliwego przykładania się do wsparcia ubogich ${ }^{19}$ portrety jej i Stanisława Mieroszewskiego, malowane na blasze przez Józefa Peszkę, zawiesić w kaplicy ubogich na Wawelu ${ }^{20}$. W tej kaplicy odprawiono, w miesiąc po śmierci

pomocy dzieciom w drugiej połowie XIX i na początku XX wieku, „Przegląd Historyczno-Oświatowy" 2004, nr 1/2, s. 85-101.

${ }^{13}$ P.P. Gach, Udział zakonów w działalności dobroczynnej na ziemiach polskich w XIX wieku, „Summarium” 2001/2002, 30/31, s. 135-149.

14 A. Jougan, Ks. Prymas Woronicz. Monografia, cz. 1-2, Lwów 1908; A. Czartoryski, Pochwała Jana Pawła Woronicza czytana na posiedzeniu Towarzystwa Przyjaciół Nauk dnia 30 kwietnia 1830 r., Puławy 1830.

${ }^{15}$ Archiwum Narodowe w Krakowie [dalej: ANK], Towarzystwo Dobroczynności w Krakowie [dalej TDK], sygn. 29/547/1, Protokoł pierwszy posiedzeń Towarzystwa Dobroczynności w Krakowie, 1816-1827, 1 grudnia 1816, s. 4; Pamiętnik Towarzystwa Dobroczynności Krakowskiego wydany z powodu obchodzonego $w$ d. 24 i 25 czerwca 1866 r. pięćdziesiątletniego Jubileuszu wskrzeszenia w roku 1816 tegoż Towarzystwa, Kraków 1866, s. 74.

${ }^{16}$ ANK, TDK, sygn. 29/547/1, Protokoł pierwszy..., sesja 8 kwietnia 1821, s. 209-210.

${ }^{17}$ ANK, TDK, sygn. 29/547/1, Protokoł pierwszy..., sesja 29 kwietnia 1821, s. 213.

${ }^{18}$ K. Koźmian, Pamiętnik [...] wspomnienia od 1780 do roku 1815, Poznań 1858, s. 60; J. Śniadecki, Listy [...] w sprawach publicznych od 1788 do 1830, Poznań 1878, s. 204; S. Wodzicki, Pamiętniki, s. 21, 195, 427.

19 ANK, TDK, sygn. 29/547/1, Protokoł pierwszy..., sesja 11 lutego 1821, s. 204.

${ }^{20}$ Obrazy te odbite na miedzi rozpowszechnione zostały wśród członków towarzystwa, zob. F. Wężyk, O życiu i zgonie Tekli z Wodzickich Małachowskiej Wojewodziny Krakowskiej, przez [...], Senatora Kasztelana, byłego Senatu Królestwa Polskiego, Kraków 1830. 
Małachowskiej, 16 stycznia 1830 roku, nabożeństwo żałobne. Wówczas mowę wygłosili ks. Ludwik Łętowski ${ }^{21}$ i Franciszek Wężyk, którzy wychwalali zasługi i zalety zmarłej, a nade wszystko gorliwe przykładanie się do dobra ubogich ${ }^{22}$. Ciekawych wiadomości na temat życia Małachowskiej dostarczył także dziennik ${ }^{23}$ oraz protokoły posiedzeń Towarzystwa Dobroczynności w Krakowie ${ }^{24}$.

Współcześnie wzmianki o Tekli Małachowskiej znajdujemy tylko w biogramie jej męża, Piotra Małachowskiego (ok. 1730-1799), wojewody krakowskiego, zamieszczonym w Polskim słowniku biograficznym. Możemy tam przeczytać, że Piotr:

W rok po śmierci żony poślubił (sierpień 1790) Teklę Wodzicką, córkę Eliasza, starosty krakowskiego, która wniosła mu 100 tys. złp posagu. [...] Ostatnie lata życia spędził M. w swoich dobrach. W r. 1797 sporządził na rzecz żony Tekli donację wsi Siedliska i Tęgobór. Zmarł bezpotomnie 3 XII 1799 w Niedźwiedziu i tamże został pochowany ${ }^{25}$.

\section{I dalej:}

Tekla z Wodzickich (1764-1829), córka Eliasza, starosty krakowskiego, i Ludwiki z Wielopolskich. Dama Orderu Krzyża Gwiaździstego, położyła zasługi przy organizowaniu Towarzystwa Dobroczynności w Krakowie. W lutym 1817 została pierwszą prezeską Towarzystwa. Walory osobiste i działalność społeczno-charytatywna zyskały jej ogólny szacunek, m.in. Jan Śniadecki pisał „najdawniejsza i najzacniejsza moja przyjaciółka”26.

${ }^{21}$ L. Łętowski, Mowa przy żałobnem nabożeństwie J. W. z hrabiów Wodzickich Tekli hrabinie Małachowskiej wojewodziny krakowskiej, prezesowej Towarzystwa Dobroczynności, Damy orderowej gwiaździstej powiedziana w kaplicy Towarzystwa Dobroczynności dnia 16 stycznia 1830 r. przez [...], Kraków 1830.

${ }^{22}$ F. Wężyk, dz. cyt. Istnieje jeszcze trzecia mowa-kazanie upamiętniająca Małachowską, którą podczas pogrzebu w Niedźwiedziu wygłosił ks. A. Maczakiewicz, zob. A. Maczakiewicz, Mowa przy złożeniu w grobie Niedźwiedzkim przywiezionych z Krakowa zwłok ś.p. J. W. z hr. Wodzickich hr. Tekli Małachowskiej, wojewodziny krakowskiej przez [...] plebana w Górce Kościelnickiej wd. 28 Grudnia 1829 miana. Na korzyść ubogich, Kraków 1930. Oracje te zostały ogłoszone drukiem, zob. K. Estreicher, Bibliografia polska, cz. 1, Stolecie XIX [1800-1880], t. 3: Ł-Q, Warszawa 1978, s. 56.

${ }^{23}$ Dotarłam do fragmentów dziennika z lat 1826-1828, przechowywanego w zbiorach Zakładu im. Ossolińskich we Wrocławiu. Na tym etapie badań nie jestem w stanie stwierdzić, czy jest to fragment większej całości, czy tylko w tym okresie autorka opisywała kolejne dni swego życia. Zob. Zakład Narodowy im. Ossolińskich, sygn. Manuskrypt 6641/I, Archiwum Wodzickich z Kościelnik, Dziennik i zapiski Tekli z Wodzickich Małachowskiej z lat 1826-1827.

${ }^{24}$ ANK, TDK, sygn. 29/547/1, Protokoł pierwszy posiedzeń Towarzystwa Dobroczynności w Krakowie, 1816-1827; ANK, TDK, sygn. 29/547/2, Protokoł drugi posiedzeń Towarzystwa Dobroczynności w Krakowie, 1827-1838.

${ }^{25}$ M. Złomska, Małachowski Piotr h. Nałęcz (ok. 1730-1799), [w:] PSB, t. 19, s. 409-411.

${ }^{26}$ J. Śniadecki, dz. cyt., s. 204. 
Testamentem zapisała 12 tys. złp na edukację dzieci w Niedźwiedziu. Zmarła 22 grudnia 1929, pochowana obok męża w Niedźwiedziu ${ }^{27}$.

Sporadycznie wzmianki o Tekli Małachowskiej pojawiają się także w opracowaniach dotyczących rodziny Wodzickich ${ }^{28}$ i życia towarzyskiego i artystycznego Krakowa ${ }^{29}$.

Tekla Wodzicka urodziła się 1 stycznia 1764 roku. Dzień zapamiętano w rodzinie z dwóch powodów: pierwszym były narodziny Tekli, drugim śmierć Michała Wodzickiego, podkanclerzego koronnego, brata ojca. Tekla była najmłodszą z czterech córek Eliasza i Ludwiki. Wychowywała się pod okiem matki w zamku w Stopnicy. Później mieszkała i nabierała ogłady towarzyskiej w Mikuleńcach na dworze babki Ludwiki z Mniszchów Potockiej, hetmanowej koronnej i kasztelanowej krakowskiej. Jak zaznacza Wężyk, to piękne przymioty młodey panienki skłoniły babkę do wzięcia wnuczki na wychowanie, aby u jej boku postępowała $w$ dalszem kształceniu umysłu $i$ serca $^{30}$. Już wtedy rozwinęły się charakterystyczne cechy osobowości, które zaważyły na jej dalszym losie. Była tkliwa, cierpliwa, uprzeyma, a wraz wesoła, dla dobra babki i w trosce o nią umiała zrezygnować z bali, rautów i innych uciech, które sa naysłodsza dla młodości ponętą. Stała się oparciem dla hetmanowej, pielęgnowała ją i starała się, aby leciwej babce resztę życia umilić31.

Po śmierci Ludwiki Potockiej wróciła do Stopnicy, gdzie stała się zaraz naypierwsza [...] ozdobą ${ }^{32}$ rodzinnego domu. Wkrótce jednak postanowiono wydać ją za mąż. Rodzinne perturbacje związane z wyborem odpowiedniego kandydata zakończyły się i - jak stwierdził Wężyk - jej wybór wypadł na stronę rozsąd$k u$, a rękę $i$ serce zyskał owdowiały rok wcześniej Piotr Małachowski, mąż dojrzały, a wręcz posunięty w latach, ale polskiey duszy ${ }^{33}$.

Jak wyglądało wspólne życie małżonków, przebywających w Warszawie podczas Sejmu Wielkiego, bojów o konstytucję dla Rzeczypospolitej, euforii po jej podpisaniu, a potem rozdarcia społecznego i walk związanych z konfederacją barską, nie wiemy. Wężyk opisał ten okres życia Tekli w kilku zdaniach. Wspomniał, że wniosła do domu męża słodką uprzejmość, a małżeństwo otworzyło się przed

${ }^{27}$ M. Złomska, dz. cyt., s. 410

28 A. Gerhardt, Rodzina Wodzickich w Krakowie w XVIII i XIX wieku, Kraków 2001.

${ }^{29}$ I. Homola-Skąpska, W salonach $i$ w traktierniach Krakowa, „Rocznik Biblioteki Naukowej PAU i PAN w Krakowie" 2000, R. 45, s. 191-228.

${ }^{30}$ F. Wężyk, dz. cyt.

31 Tamże.

32 Tamże.

33 Tamże. 
nią pasmo [...] życia i powinności i obszernieyszego działania ${ }^{34}$. Po ślubie z Piotrem, urzędnikiem państwowym, prowadziła dom otwarty dla ludzi różnych stanów i opcji politycznych, wielokrotnie musiała godzić ludzi o ścierających się poglądach, łagodzić spory, a potem słodzić [...] rozlaną gorycz po wszystkich sercach, z powodu smutnych kraiowych wypadków ${ }^{35}$. Trudno jednoznacznie określić, jakie poglądy polityczne miał Małachowski i czy rzeczywiście serca jego domowników po upadku Rzeczypospolitej opanowała rozpacz. Maria Złomska pisała, że odsunął się od spraw politycznych. Na akcie konfederacji barskiej złożył tylko swój podpis, ale w działaniach konfederatów nie brał udziału. Brak zaangażowania wytykał mu nawet życzliwy anonim z Warszawy, pisząc, że uchylał się od wszystkiego $^{36}$. Wężyk przekonywał jednak, że nadzieja na odzyskanie niepodległości ożywiała umysł małżonka w smutnych wypadkach dla kraiu ${ }^{37}$. A przyczyną odsunięcia się w domowe zacisze był stan zdrowia, który w tym okresie znacznie się pogorszył. Dlatego wszystkie zajęcia Tekli musiały skoncentrować się na ciągłym staraniu około upadaiącego na siłach małżonka ${ }^{38}$. Troszczyła się o niego i napełniała nadzieją, którą przechowała $w$ swem sercu $i$ domu nawet $w$ tych czasiech, kiedy iuż Polska skonała ${ }^{39}$. O tym, że było to dziesięć lat spędzonych $w$ nieprzerwaney i przykładney zgodności ${ }^{40}$, świadczą nie tylko zapewnienia autorów mów pogrzebowych, ale także zapisy w pamiętnikach i listach członków rodziny Tekli.

Po śmierci męża w 1799 r. Małachowska osiadła na stałe we wsi Siedliska pod Krakowem, którą wybrała sobie na mieszkanie jeszcze za życia Piotra ${ }^{41}$. W pierwszych latach wdowieństwa myślała tylko o spełnieniu ostatniej woli męża i o zachowaniu pamiątek po nim. Dworek w Siedliskach stał się domem dla wielu jej krewnych, a dla przyjaciół gościnnym i pożądanym miejscem spotkań towarzyskich i rozmów na tematy społeczne i patriotyczne. W zaciszu domowym Małachowska podejmowała wiele działań zmierzających do poprawy stanu dóbr, w których osiadła. Wioskę przyozdabiała nie $w$ okazałe budowle ani $w$ kosztowne ogrody ${ }^{42}$, ale budowała w niej skromne i wygodne chaty dla włościan, kazała sadzić drzewa, założyła szkółkę dla dzieci chłopskich. Była matką ludu wieyskiego, jak nazywał ją

\footnotetext{
${ }^{34}$ Tamże.

35 Tamże.

${ }^{36}$ M. Złomska, dz. cyt.

${ }^{37}$ F. Wężyk, dz. cyt.

38 Tamże.

39 Tamże.

40 Tamże.

${ }^{41}$ Wężyk podkreślał, że sama wybrała sobie te wsie: Gdy mąż dostatni, z licznych dóbr swoich ofiarował iey wybór bezwarunkowy przyszłey własności, miasto zwrócenia swych oczu na okazałe pałace albo rozległe włości, obrała sobie dwie skromne wioski i szczupły domek. Por. M. Złomska, dz. cyt.

${ }^{42}$ F. Wężyk, dz. cyt.
} 
Wężyk, starała się zgadywać potrzeby włościan, troszczyła się o cisnące się do boku swego dziadki wieśniaków $w^{43}$. Tym zaskarbiła sobie pamięć włościan i zgromadzała zawczasu skarb błogosławieństw powszechnych ${ }^{44}$.

Nauczona doświadczeniem męża, który do końca życia prowadził spory majątkowe z rodziną pierwszej żony, toruiąc sobie ścieszkę do spokoyności i wdzięczności następcó $w^{45}$, wcześnie rozdała cały odziedziczony majątek między najbliższych krewnych, zastrzegając sobie prawo pobierania minimalnego dochodu z niektórych dóbr. W ten sposób zapobiegła wszelkim spadkowym sporom. Podobnież postąpiła z dożywotnimi dobrami.

Sześć lat po śmierci męża, w 1805 r., zmarli najbliżsi członkowie jej rodziny: najpierw ojciec, a potem siostra Konstancja Mieroszewska (24 listopada) ${ }^{46} \mathrm{w}$ jej domu dokonała żywota. Małachowska przygarnęła osierocone córki siostry: Fe$\operatorname{licję}^{47}$ i Ludwikę, które traktowała jak własne dzieci. Dała im dobre wychowanie i wykształcenie, a równocześnie wpajała miłość bliźniego, uczyła troszczyć się o słabych i biednych, nie zapominając o miłości do ojczyzny. Wychowane przez nią panienki w dorosłym życiu stanowiły wzór dla kolejnych pokoleń. Sobiesław Mieroszewski, wspominając swojego ojca Stanisława, pisał, że nie lubił Felicji, gdyż była doskonała. Żeby choć najmniejszy grzeszek popełniła, toby poznała, co skromność, co pobłażliwośćt ${ }^{8}$. Małachowska przeżyła starszą z przysposobionych córek, Ludwikę Siemieńską ${ }^{49}$. Śmierć Ludwiki przywiodła jej ojca, Józefa Mieroszewskiego, do ciężkiej choroby, Tekla starała się więc wspierać go w nieszczęściu. W roku 1811 zmarła matka Małachowskiej.

Gdy Kraków został włączony do Księstwa Warszawskiego, potrzeba stabilizacji, tęsknota za życiem towarzyskim, balami i rautami, a także troska o powierzone jej opiece dzieci skłoniły Małachowską do przeprowadzki do tego miasta. Zamieszkała w pałacu Małachowskich, zajmującym narożnik Rynku Głównego i ulicy Szewskiej ${ }^{50}$. W latach 1811-1827 prowadziła gospodarstwo domowe wraz z siostrą Elżbietą Potulicką ${ }^{51}$. Obie panie, wspierając się wzajemnie, poświęcały czas

43 Tamże.

44 Tamże.

45 Tamże.

${ }^{46}$ Konstancja była żoną Józefa Mieroszewskiego herbu Ślepowron.

47 Felicja z Mieroszewskich Wężyk (1794-1876) - żona Franciszka Wężyka, autora mowy pogrzebowej.

48 S. i S. Mieroszewscy, dz. cyt., s. 202.

${ }^{49}$ Ludwika (ur. ok. 1800) - żona Wincentego Siemieńskiego.

50 J. Wawel-Louis, Przechadzki kronikarza po Rynku krakowskim, Kraków 1890, s. 147; A. Gerhardt, dz. cyt., s. 21.

51 L. Hayto, Potulicki Bonawentura Michał h. Grzymała (1756-1805), [w:] PSB, t. 28, Wrocław 1984-1985, 251-252. 
na życie towarzyskie i działalność dobroczynną. Z chwilą zamieszkania z siostrą życie Tekli Małachowskiej wpisuje się w schemat cnotliwej wdowy, wykreowany jeszcze w XVII wieku ${ }^{52}$. Wdowieństwo sióstr Małachowskiej i Potulickiej różni się jednak od staropolskiego wzorca. Obie wyniosły z domu zamiłowanie do życia towarzyskiego, które jednak starały się wieść tak, aby wykorzystać je do prowadzenia działalności dobroczynnej. Małachowska prowadziła dom otwarty, który był prawdziwą świątynią staropolskiej gościnności. Przyjmowała wszystkich, którzy zawitali pod jej dach. Każdy otrzymał to, czego potrzebował, jedni wsparcie finansowe, inni dobre słowo. Przez czterdzieści lat nikt nie odszedł z jej domu, nie otrzymawszy pomocy. Nie prowadziła wystawnego życia, a oszczędności przeznaczała dla biednych znajdujących się pod opieką Towarzystwa. Była tak hojna, że niejednokrotnie zastanawiano się, jakim dziwnym sposobem wydatek nie przeszedł miary przychodów $w^{53}$. Bywali u niej nawet ci, którzy nie zawsze się z nią zgadzali, ale chcieli jej pomagać, bo na tem wyższość istotna prawdziwey cnoty polega, że iey ci nawet hołdują, którzy dosięgnać nie moga ${ }^{54}$. Przez cały czas, mimo trosk i kłopotów rodzinnych, zachowywała pogodną twarz, była delikatna i wrażliwa. Umiała trafić do serca każdego, wszystkich napełnić optymizmem i rozlać na każdy przedmiot rozmowy piękna swey duszy wesołośćc 55 .

W Krakowie poświęciła się także pracy nad uprzątnięciem żebractwa $\mathrm{z}$ ulic miasta i umieszczeniem bezdomnych w domu przyzwoitego schronienia. Wspierając działania kuzyna Stanisława Wodzickiego, a także Stanisława Mieroszew-

${ }^{52}$ Wdowa w epoce staropolskiej cieszyła się największym szacunkiem w systemie świeckich wzorców kobiecych. Realizowała bowiem wzorzec zarówno mężnej i pobożnej białogłowy, jak i hojnej fundatorki, przekazującej legaty na instytucje kościelne (kaplice, klasztory i kościoły) oraz świeckie (szkoły, bursy i szpitale). Stan wdowi w przypadku kobiet świeckich kojarzony był ze świętością i wyrzeczeniem się świata. Wdowieństwo dotyczyło głównie kobiet $\mathrm{z}$ warstw magnackich, które w rzeczywistości prawno-rodzinno-społecznej doby sarmackiej mogły wziąć na siebie część męskich ról i w ramach tego stanąć na czele rodzin lub też przejmować zarząd nad swymi majątkami. „[...] wdowi stan, wprowadzając do statutu niewiasty niezliczone potencjalne uciążliwości, wprowadzał też mnogość rewolucyjnych wręcz przywilejów”, zob. U. Kicińska, Rola wdowy w rodzinie i społeczeństwie staropolskim na podstawie polskich drukowanych oracji pogrzebowych XVII wieku, „Sensus Historia” 2013-14, 12, s. 135-148; taż, Wzorzec szlachcianki w polskich drukowanych oracjach pogrzebowych XVII wieku, Warszawa 2013. O wdowie pisali także: A. Karpiński, Kobieta w mieście polskim w drugiej połowie XVI i XVII wieku, Warszawa 1995; C. Kuklo, Kobieta samotna w społeczeństwie miejskim u schyłku Rzeczypospolitej szlacheckiej. Studium demograficzno-społeczne, Białystok 1998; tenże, Demografia Rzeczypospolitej przedrozbiorowej, Warszawa 2009, s. 285-287; H. Wiśniewska, Świat płci żeńskiej baroku zaklęty w słowach, Lublin 2009; I. Pugacewicz, Wizerunek dobrej wdowy w opiniach Ojców Kościoła i moralistów w epoce wczesnonowożytnej, [w:] Rodzina i gospodarstwo domowe na ziemiach polskich w XV-XX wieku. Struktury demograficzne, społeczne i gospodarcze, red. C. Kuklo, Warszawa 2008, s. 247-260.

${ }^{53}$ F. Wężyk, dz. cyt.

54 Tamże.

55 Tamże. 
skiego i innych znajomych ze środowiska arystokratycznego, rozpoczęła działalność w tworzącym się Towarzystwie Dobroczynności w Krakowie, opiekującym się ubogimi. Praca wyzwoliła w niej nowe pokłady wrażliwości, ciepła, troski i współczucia dla chorych, biednych, bezdomnych, inwalidów. Nie ustawała w poszukiwaniu nowych pomysłów nad pomnożeniem środków ku utrzymaniu mnożącey się corocznie i nie szczupley liczby nędzarzy ${ }^{56}$.

Już 12 stycznia 1817 roku, na czwartym zebraniu Towarzystwa, zaproponowała, aby zwrócić się do rządzących w trzech państwach zaborczych, pod których protekcją znajdował się Kraków, aby utworzyli fundusz na utrzymanie biednych będących pod opieką Towarzystwa ${ }^{57}$. Przewidywano jednak, że gromadzenie środków na fundusz potrwa jakiś czas, dlatego na tym samym posiedzeniu Zofia z Badenich Popielowa wniosła projekt, aby poprosić właścicieli domów, żeby żywili ubogich. Zgodzono się wybrać kilka dam z towarzystwa, które miały kwestować $\mathrm{w}$ domach mieszczan. Tekla zaprosiła ochotniczki na posiedzenie prywatne, zorganizowane w jej domu 14 stycznia 1817 roku. Celem spotkania było zorganizowanie kwesty. Odbyła się ona jeszcze w styczniu i przyniosła 4390 złotych polskich oraz różne zapisy, które miały być później zrealizowane ${ }^{58}$. 19 stycznia złożyła na rzecz ubogich „skrypt” na 500 złp z prowizją ośm od sta ${ }^{59}$. Dnia 22 stycznia odbyło się kolejne prywatne posiedzenie dam, na którym panie złożyły sprawozdanie z kwesty, a już 26 stycznia Małachowska podsumowała ją na szóstym posiedzeniu Towarzystwa, donosząc, że zebrano 4309 złp w gotówce, a ponadto wiele zapisów, które miały być wypłacone w późniejszym terminie. Podkreśliła przy tym, że niepierwszy to raz, gdzie te damy okazały szlachetność sposobu myślenia i czułość serca swego, w każdych bowiem zdarzających się okolicznościach dały tego tysiaczne przykłady, i tak teraz na odgłos cierpiącej ludzkości pospieszyły z naywiększym utrudzeniem bez różnicy stanu i wieku, pomimo zimnej pory roku, i naygorszej chwili $z$ uszkodzeniem własnego zdrowia na ratunek nieszczęśliwych ${ }^{60}$. Akcja spotkała się z pozytywnym odbiorem, dlatego Towarzystwo Dobroczynności wydało odezwę, oświadczając tymże Damom najczulsze podziękowania, z chluba wyznanie, iż nasze Polki iako przywiązane Córy, dobre Żony, staranne Matki, przychylne do Ojczyzny Obywatelki, nakoniec mite i uprzeyme w obcowaniu Towarzyskim, przynoszace prawdziwe szczęście w prywatnym pożyciu, stusznie nazwane bydź mogq wzorem płci piękney wszystkich narodów ${ }^{61}$.

\footnotetext{
${ }^{56}$ Tamże.

${ }^{57}$ ANK, TDK, sygn. 29/547/1, Protokoł pierwszy..., posiedzenie 12 stycznia 1817, s. 6.

58 Tamże, s. 6.

${ }^{59}$ ANK, TDK, sygn. 29/547/1, Protokoł pierwszy..., posiedzenie 19 stycznia 1817, s. 8.

${ }^{60}$ Tamże, s. 9.

${ }^{61}$ ANK, TDK, sygn. 29/547/1, Protokoł pierwszy..., posiedzenie 26 stycznia 1817, k. 9.
} 
Małachowska dbała o to, aby nie zaprzestano propagowania Towarzystwa w tych miastach i krajach, gdzie znajdowały się skupiska rodaków, i tą drogą starała się uzyskać wsparcie dla podopiecznych. W owym duchu na XXIV posiedzeniu złożyła wniosek, do którego przychyliła się Rada Towarzystwa, aby rozesłać do miast i miasteczek Europy oświadczenie w językach polskim, francuskim, rosyjskim i niemieckim o utworzeniu i działalności Towarzystwa Dobroczynności w Krakowie ${ }^{62}$.

W roku 1817 w bocznym skrzydle Zamku na Wawelu otworzono dom opieki i przyzwoitego schronienia dla bezdomnych, starców, kalek i dzieci, składający się z 22 sal. Na posiedzeniu 23 stycznia 1820 roku, na mocy nowego statutu Towarzystwa, wybrano opiekunów, nazywanych „ojcem” lub „matką”, dla każdej sali. Zobowiązali się oni, że przynajmniej raz w miesiącu będą odwiedzać swoją salę, prowadzić rejestr ubogich, pomagać w pilnowaniu porządku i dobrych obyczajów, otaczać pensjonariuszy opieką, organizować zabezpieczenie potrzeb. Będą też zbierali środki na ich reperację $e^{63}$ i dostarczali sprzęty, pościel, ubrania, żywność i pieniądze ${ }^{64}$. W wyniku losowania Elżbieta Potulicka dostała pod opiekę salę siedemnastą, a Tekla Małachowska - dziewiętnastą. W roku 1821 Małachowska przeznaczyła na urządzenie swojej sali 269 złp i 20 gr, Potulicka 58 ${ }^{65}$. W roku 1828 Tekla Małachowska obdarowała salę dwudziestą 10 złp i 30 pączkami66. Z okazji różnych świąt (Boże Narodzenie, Wielkanoc, Zielone Świątki) Tekla, ale także inni opiekunowie dawali podopiecznym drobne kwoty, najczęściej po kilka złotych.

Główną formą aktywności kobiet w towarzystwie było inicjowanie i realizowanie działalności mającej na celu zbiórkę pieniędzy na cele statutowe. W roku 1817 w czasie świąt Wielkiej Nocy zorganizowano kwestę: Damy rozebrawszy między siebie kościoły, w których w Wielki Piątek i w Wielka Sobotę odbyły kwestę, oddały na rece swej Prezesowej JW. Małachowskiej do Kassy Towarzystwa Dobroczynności 1800 złp, a reszta została rozdana pomiędzy wstydzacych się prosić ubogich, niektóre klasztory i na Szpital żydowski ${ }^{67}$. 1 marca Małachowska złożyła kwit na 2000 złp, które z loterii uzbierała i do kasy Towarzystwa oddała ${ }^{68}, 13$ kwietnia damy rozebrawszy między siebie kościoły, w których w Wielki Piątek $i$ Wielka Sobotę odbyły kwestę, oddały przez ręce swej prezesowej do kasy towarzystwa 1800 zł, a 1200 rozdały wśród wstydzących się żebrać69,

${ }^{62}$ ANK, TDK, sygn. 29/547/1, Protokoł pierwszy..., posiedzenie 6 lipca 1818, s. 31.

${ }^{63}$ ANK, TDK, sygn. 29/547/1, Protokoł pierwszy..., posiedzenie 23 stycznia 1820, s. 161-162.

${ }^{64}$ R. Skowron, Towarzystwo Dobroczynności: organizacja i działalność Ogólnego Schronienia Ubogich na Wawelu (1816-1846), „Studia do Dziejów Wawelu” 1991, t. V, s. 486.

${ }^{65}$ ANK, TDK, sygn. 29/547/1, Protokoł pierwszy..., posiedzenie 21 stycznia 1821, k. 202.

${ }^{66}$ ANK, TDK, sygn. 29/547/2, Protokoł drugi..., posiedzenie 13 kwietnia 1828, k. 18-19.

${ }^{67}$ Tamże, , sesja 22 marca 1818 roku, k. 79; T. Kargol, dz. cyt., s. 177.

${ }^{68}$ ANK, TDK, sygn. 29/547/1, Protokoł pierwszy..., posiedzenie 1 marca 1817, s. 22.

${ }^{69}$ ANK, TDK, sygn. 29/547/1, Protokoł pierwszy..., posiedzenie 13 kwietnia 1817, s. 27. 
W Wielki Piątek i w Wielką Sobotę 1818 roku, obchodząc krakowskie kościoły, damy zebrały $3052 \mathrm{złp} \mathrm{i} 2 \mathrm{gr}^{70}$. W roku 1823 kwesta wielkanocna przyniosła kwotę 5625 złp 20 gr, z tego do kasy Towarzystwa oddano 360 złp, do klasztoru Panien Miłosiernych i do Bractwa Miłosierdzia 976 złp, dla ubogich wstydzących się żebrać - 1049 złp 20 gr $^{71}$. W roku 1824 kwesta przy Grobie Pańskim w kościołach przyniosła 112 złotych i 12 groszy, którą rozdzielono między Towarzystwo, krakowskie kościoły i klasztory, a część rozdano ubogim wstydzącym się żebrać. W Wielki Piątek 1826 roku wraz z Teklą Małachowską w kościołach kwestowały: Anna z Jabłonowskich Wodzicka, Elżbieta Potulicka, Zofia Potocka, Teresa Grodzicka z córką. Tego dnia zebrano 4144 złp i 13 gr $^{72}$. W roku 1828 Tekla Małachowska kwestowała z Anną Wodzicką, Petronelą Wodzicką, Karoliną Mycielską, Justyną Russocką, Salomeą Wielhorską i Zofią z Badenich Popielową, zebrały 2759 złp 15 gr $^{73}$.

Małachowska jako pierwsza zaczęła w Krakowie urządzać imprezy dobroczynne. Nie było zabawy towarzyskiej, na której nie szukałaby nowej dla biednych pomocy; nie byłoby chwili, w której przypomniała o świętym celu swey troskliwości i sta$\mathrm{ranh}^{74}$. Jej działania cieszyły się dużym powodzeniem i przynosiły owoce. Pierwszy zorganizowany przez nią w $1817 \mathrm{r}$. koncert przyniósł Towarzystwu czysty dochód w wysokości $1270 \mathrm{złp}^{75}$. Na sesji 26 kwietnia roku 1818 zaproponowała, aby na rzecz ubogich $w$ domu schronienia znayduiących się urządzić bal z fajerwerkami w Sukiennicach, ostatecznie jednak - z powodu dużych kosztów związanych w wynajęciem sali - zdecydowano, że zostanie on zorganizowany w sali Macieja Knotza ${ }^{76}$. Bal odbył się 27 czerwca, a pokaz sztucznych ogni - 30 czerwca. Na rzecz ubogich na balu zebrano $629 \mathrm{złp} \mathrm{i} 9 \mathrm{gr}$, a na fajerwerkach 1357 złp i $7 \mathrm{gr}^{77}$.

Małachowska z własnej kieszeni wypłacała dla podopiecznych Towarzystwa, od jego założenia do roku 1828, rocznie $240 \mathrm{złp}$. W testamencie zrobiła zapis na sumę 5000 złp na rzecz domu opieki, na nieruchomości pod numerem L337 w Gminie III miasta Krakowa ubezpieczonej ${ }^{78}$.

Wspierał ją w tych działaniach prezes Stanisław Mieroszewski (1756-1824), ordynat mysłowski. Połączeni troską o los najbiedniejszych mieszkańców Krakowa współpracowali, kierując Towarzystwem. Jak pisze Wężyk, szli przez lat kilka w za-

\footnotetext{
70 ANK, TDK, sygn. 29/547/1, Protokoł pierwszy..., posiedzenie 29 marca 1818, s. 79.

${ }^{71}$ ANK, TDK, sygn. 29/547/1, Protokoł pierwszy..., posiedzenie 6 kwietnia 1823, k. 286.

72 ANK, TDK, sygn. 29/547/1, Protokoł pierwszy..., posiedzenie 21 maja 1826, k. 426.

${ }^{73}$ ANK, TDK, sygn. 29/547/2, Protokoł drugi..., posiedzenie 13 kwietnia 1828, k. 19-20.

${ }^{74}$ F. Wężyk, O życiu i zgonie Tekli...

75 A. Gerhardt, dz. cyt., s. 41; Z. Krzyżanowska, dz. cyt., s. 183 i nast.

${ }^{76}$ ANK, TDK, sygn. 29/547/1, Protokoł pierwszy..., posiedzenie 26 kwietnia 1818, s. 83-84.

77 ANK, TDK, sygn. 29/547/1, Protokoł pierwszy..., posiedzenie 5 lipca 1818, s. 92.

${ }^{78}$ F. Wężyk, dz. cyt.
} 
wody, kto dzielnicy lub rychley przyniesie nędznym nowy i nadspodziany zasitek ${ }^{79}$. Gdy Mieroszewski zmarł, podwoiła swoje wysiłki dla dobra Towarzystwa.

Małachowska z Potulicką, wiodąc spokojne i szczęśliwe życie, dożyły wieku, w którym się sędziwość poczyna ${ }^{80}$. Gdy 11 lipca 1827 roku Potulicka zmarła, Małachowska - według Wężyka - zniosła ten cios z rzadkim męztwem i poddaniem się naywyższey woli ${ }^{81}$. Jednak ból po stracie siostry, trudy dnia codziennego i wieloletnia praca na rzecz Towarzystwa mocno nadwerężyły jej zdrowie. Kilka tygodni po śmierci siostry zachorowała. Lekarze obawiali się o jej życie. Nigdy już nie wróciła całkowicie do pełni sił. W roku 1829 Małachowska wezwała kobiety:

Towarzystwo Dobroczynności widząc w zeszłym roku wzniesione swe usiłowania tak pomyślnym i świetnym skutkiem z odbytej loterii fantowej na korzyść ubogich, ośmiela znowu ponowić uprzejmie prośbę w celu trudnienia JWW i WW Damy przykrą zasługą zbierania fantów na rzecz takieyże Loteryi w rok bieżącym odbądź się mającej. Towarzystwo dobroczynności ożywione doświadczeniem, z jaką przykładną gorliwością i poświęceniem się JWW i WW Damy pospieszają, gdy chodzi o przyniesienie ulgi cierpiącej ludzkości, czyni sobie niepłonną nadzieję, iż czułe ich serca nie zdołają odmówić tej trudnej i przykrej posługi, w celu wsparcia Instytutu dającego przytułek 340 osobom niedołężnym, wiekiem osłabionym i pozbawionym wszelkich środków utrzymania życia. Jeżeli są moralne nagrody za dobroczynne i usłużne czyny mające tak szlachetne i chwalebne cele, znajdzie je każda z szanownych Dam w swem tkliwem sercu wylanym bez zwątpienia dla dobra i użytku cierpiącey nędzy ${ }^{82}$.

Mimo niedomagań nie przestawała pracować w Towarzystwie Dobroczynności. Krewni, przyjaciele, domownicy, słudzy, włościanie nie zaobserwowali żadnej zmiany w jej intensywnym trybie życia. Nikt więc nie przeczuwał, że po dwóch latach cierpienie powróci. I tym razem udało jej się uniknąć śmierci, ale na krótko. Kilka miesięcy później choroba zaatakowała ze zdwojoną siłą. Lekarze zalecili jej powrót do Krakowa, aby mogli przez cały czas czuwać nad nią. Mimo ich wysiłków nie udało się przywrócić Małachowskiej do zdrowia. Zmarła 22 grudnia $1829 \mathrm{roku}^{83}$.

Mimo iż na pogrzeb przeznaczyła ona tylko 2000 złp, odbył się on z wszystkimi honorami 24 grudnia 1829 roku. Zebranemu duchowieństwu w obrzędzie przeprowadzenia zwłok do świątyni przewodniczył biskup pomocniczy krakowski

\footnotetext{
${ }^{79}$ Tamże.

${ }^{80}$ Tamże.

81 Tamże.

82 ANK, TDK, sygn. 29/547/2, Protokoł drugi..., posiedzenie 2 marca 1828, s. 9-10.

${ }^{83}$ F. Wężyk, dz. cyt.
} 
Franciszek Zglenicki (1767-1841). Hołd zmarłej oddali także księża Stachorowski i Dzianot, współpracujący z nią w Towarzystwie Dobroczynności. Następnie zwłoki przewieziono do Niedźwiedzia, dóbr, należących niegdyś do jej męża Piotra Małachowskiego, który tam został pochowany, a będących własnością Stanisława Wodzickiego. Tam 25 grudnia odbyły się kolejne uroczystości pogrzebowe ${ }^{84}$.

Przed śmiercią Tekla z Wodzickich Małachowska przekazała ostatnią wolę, która według Wężyka stanowiła dowód na to, że wydająca ją kobieta była wzorem tkliwości i skromności złączoney z rzadkim rozsąakiem ${ }^{85}$. Jej wykonawcą został ukochany jeszcze żyjący brat hrabia Józef Wodzicki. Małachowska wyznaczyła kontynuatorów ważniejszych przedsięwzięć, którymi kierowała. Prezeską Towarzystwa Dobroczynności uczyniła Petronelę z Jabłonowskich Wodzicką (1770-1859), małżonkę brata Józefa. Rozdysponowała też wszystkimi swoimi dobrami, stugom zostawiła dom po śmierci i służbę u ludzi znamienitych ${ }^{86}$.

Tekla z Wodzickich Małachowska, choć obecnie niemal zapomniana, dla współczesnych sobie była kobietą niezwykłą. Po śmierci męża Piotra Małachowskiego zamieszkała w Stopnicy pod Krakowem. Do życia publicznego powróciła w okresie Księstwa Warszawskiego. Wtedy przeniosła się do Krakowa, kładąc zasługi przy organizowaniu Towarzystwa Dobroczynności. W lutym 1817 roku została pierwszą prezeską Towarzystwa. Troszczyła się o swoich podopiecznych. Jako jedna z pierwszych w Polsce zaczęła organizować koncerty charytatywne i bale, na których urządzała kwesty i zbierała pieniądze dla Towarzystwa. Te działania, kontynuowane przez jej towarzyszki, a potem następczynie, nadały ton całej dziewiętnastowiecznej działalności charytatywnej kobiet. Walory osobiste i działalność społeczno-charytatywna Małachowskiej zyskały jej powszechny szacunek. Do grona przyjaciół zaliczali ją nie tylko przedstawiciele rodów magnackich osiadłych w Krakowie, ale także czołowi intelektualiści epoki, m.in. Jan Śniadecki. 16 stycznia 1830 roku w kaplicy na Wawelu odprawiono żałobne nabożeństwo za jej duszę. Wygłoszone na nim wtedy kazanie wydrukowano w „Pamiętniku Towarzystwa Dobroczynności”, a kilka lat później wpisano do pamiątkowej Księgi wspomnień zmarłych dobroczyńców Zakładu i odznaczających się poświęceniem członków Towarzystwa Dobroczynności w Krakowie ${ }^{87}$.

${ }^{84}$ Tamże.

85 Tamże.

${ }^{86}$ L. Łętowski, dz. cyt., s. 7-8.

${ }^{87}$ Archiwum Narodowe w Krakowie, sygn. 29/547/24, Księga wspomnień zmarłych dobroczyńców Zakładu i odznaczających się poświęceniem członków Towarzystwa Dobroczynności w Krakowie. 


\section{LITERATURA}

\section{ARCHIWA}

Archiwum Narodowe w Krakowie, Towarzystwo Dobroczynności w Krakowie, sygn. 29/547/24, Księga wspomnień zmarłych dobroczyńców Zakładu i odznaczających się poświęceniem członków Towarzystwa Dobroczynności w Krakowie.

Archiwum Narodowe w Krakowie, Towarzystwo Dobroczynności w Krakowie, sygn. 29/547/1, Protokoł pierwszy posiedzeń Towarzystwa Dobroczynności w Krakowie, 1816-1827.

Archiwum Narodowe w Krakowie, Towarzystwo Dobroczynności w Krakowie, sygn. 29/547/1, Protokoł drugi posiedzeń Towarzystwa Dobroczynności w Krakowie, 1827-1838.

Zakład Narodowy im. Ossolińskich, sygn. Manuskrypt 6641/I, Archiwum Wodzickich z Kościelnik, Dziennik i zapiski Tekli z Wodzickich Małachowskiej $\mathrm{z}$ lat 1826-1827.

\section{OPRACOWANIA}

Barnaś E. (1997). Powstanie i pierwsze lata działalności Krakowskiego Towarzystwa Dobroczynności (1816-1820). „Zeszyty Naukowe WSP w Rzeszowie. Pedagogika i Psychologia” z. 3, s. 87-99.

Bąk J. (1975). Opieka społeczna nad sierotami w Krakowskim Towarzystwie Dobroczynności w latach 1816-1916. „Rocznik Krakowski” t. XLVI, s. 99-112.

Bek J. (1916). Opieka nad sierotami. Lwów.

Bieniarzówna J. (1976). Mieroszewski (Miroszewski, Mieroszowski) Stanisław h. Ślepowron. W: E. Rostworowski (red.). Polski słownik biograficzny [dalej: PSB], t. 21. Kraków-Wrocław, s. 2-3.

Bystrzonowski A. (1937). Bystrzonowski Antoni Onufry h. Starykoń. W: W. Konopczyński (red.). PSB.T. 3. Kraków, s. 173-174.

Czartoryski A. (1830). Pochwała Jana Pawła Woronicza czytana na posiedzeniu Towarzystwa Przyjaciół Nauk dnia 30 kwietnia 1830 r. Puławy.

Dydusiak L. (1938). Zagadnienie żebractwa w Polsce. Borysław.

Estreicher K. (1978). Bibliografia polska, cz. 1: Stolecie XIX [1800-1880], t. 3: Ł-Q. Warszawa, s. 56.

Gach P.P. (1973). Sieć szpitali w diecezji krakowskiej w połowie XVIII wieku. Lublin. Gach P.P. (2001/2002). Udział zakonów w działalności dobroczynnej na ziemiach polskich w XIX wieku, „Summarium” 30/31, s. 135-149.

Gajda M. (1988). Krakowskie Towarzystwo Dobroczynności w zbiorach Biblioteki Jagiellońskiej. „Biuletyn Biblioteki Jagiellońskiej” 38, s. 143. 
Gerhardt A. (2001). Rodzina Wodzickich w Krakowie w XVIII i XIX wieku. Kraków. Głębocki J.T. (1852). Zakłady ku ulżeniu cierpieniom bliźnich obecnie w Krakowie istniejące $z$ krótką wzmianka o dawniejszych, a dziś nie istniejących tego rodzaju. Kraków.

Górski K. (1931). Kronika Krakowa. Śmiertelność dzieci w zakładach opiekuńczych. „Opieka nad Dzieckiem” R. IX, nr i, s. 22-27.

Haratyk A. (2002). Rozwój opieki nad dziećmi i młodzieża w Galicji doby autonomicznej. Wrocław.

Haratyk A. (2004). Udział społeczeństwa krakowskiego w niesieniu pomocy dzieciom $w$ drugiej połowie XIX i na początku XX wieku. „Przegląd Historyczno-Oświatowy" nr 1/2, s. 85-101.

Haratyk A. (2007). Udział społeczeństwa galicyjskiego w opiece nad dziećmi ubogimi i osieroconymi (1867-1914). Kraków.

Hayto L. (1984-1985). Potulicki Bonawentura Michał h. Grzymała (1756-1805). W: PSB.T. 28. Wrocław, 251-252.

Homola-Skąpska I. (2000). W salonach i w traktierniach Krakowa. „Rocznik Biblioteki Naukowej PAU i PAN w Krakowie" 45, s. 191-228.

Jougan A. (1908). Ks. Prymas Woronicz. Monografia, cz. 1-2. Lwów.

Kargol T. (2007). Rola ziemianek $w$ powstaniu oraz działalności instytucji opieki społecznej i dobroczynności publicznej Lublina, Warszawy i Krakowa. W: H. Łaszkiewicz (red.). Ziemiaństwo na Lubelszczyźnie III. Panie $z$ dworów i pałaców, t. 2. Lublin, s. 167-184.

Karpiński A. (1995). Kobieta w mieście polskim w drugiej połowie XVI i XVII wie$k u$. Warszawa.

Kicińska U. (2013). Wzorzec szlachcianki w polskich drukowanych oracjach pogrzebowych XVII wieku. Warszawa.

Kicińska U. (2013-2014). Rola wdowy w rodzinie i społeczeństwie staropolskim na podstawie polskich drukowanych oracji pogrzebowych XVII wieku. „Sensus Historia" 12, s. 135-148.

Koźmian K. (1858). Pamiętnik [...] wspomnienia od 1780 do roku 181. Poznań.

Krzyżanowska Z. (1931). Dobroczynność w Krakowie. Kraków.

Kuklo C. (1998). Kobieta samotna w społeczeństwie miejskim u schyłku Rzeczypospolitej szlacheckiej. Studium demograficzno-społeczne. Białystok.

Kuklo C. (2009). Demografia Rzeczypospolitej przedrozbiorowej. Warszawa.

Łętowski L. (1830). Mowa przyżałobnem nabożeństwie J. W. z hrabiów Wodzickich Tekli hrabinie Małachowskiej wojewodziny krakowskiej, prezesowej Towarzystwa Dobroczynności, Damy orderowej gwiaździstej powiedziana w kaplicy Towarzystwa Dobroczynności dnia 16 stycznia 1830 r. przez [...]. Kraków. 
Maczakiewicz A. (1930). Mowa przy złożeniu w grobie Niedźwiedzkim przywiezionych z Krakowa zwłok ś.p. J.W. z hr. Wodzickich hr. Tekli Małachowskiej, wojewodziny krakowskiej przez [...] plebana w Górce Kościelnickiej w d. 28 Grudnia 1829 miana. Na korzyść ubogich. Kraków.

Mieroszewscy S. i S. (1964). Wspomnienia lat ubiegłych, przygot. do dr. Maria i Henryk Baryczowie. Kraków.

Palarczykowa A. (1983). Potocka z Branickich Zofia. W: S. Kieniewicz (red.). PSB.T. 27. Wrocław-Kraków, s. 747-749.

Panek B. (1986). Krakowskie organizacje charytatywne w latach 1918-1939. Kraków. Pugacewicz I. (2008). Wizerunek dobrej wdowy w opiniach Ojców Kościoła i moralistów w epoce wczesno nowożytnej. W: C. Kuklo (red.). Rodzina i gospodarstwo domowe na ziemiach polskich $w X V-X X$ wieku. Struktury demograficzne, społeczne i gospodarcze. Warszawa, s. 247-260.

Strojek L., Friedberg M. (1935). Bartsch Walenty. W: W. Konopczyński (red.). PSB.T. 1. Kraków, s. 332.

Śniadecki J. (1878). Listy [...] w sprawach publicznych od 1788 do 1830. Poznań. Wawel-Louis J. (1890). Przechadzki kronikarza po Rynku krakowskim. Kraków.

Wężyk F. (1830). O życiu i zgonie Tekli z Wodzickich Małachowskiej Wojewodziny Krakowskiej, przez [...], Senatora Kasztelana, byłego Senatu Królestwa Polskiego. Kraków.

Wiśniewska H. (2009). Świat płci żeńskiej baroku zaklęty w słowach. Lublin.

Wodzicki S. (1888). Pamiętniki [...]. Kraków.

Wodzicki Stanisław. W: Bibliografia Literatury Polskiej. Nowy Korbut, t. 6, cz. 1: Oświecenie. Warszawa 1970, s. 439-444;

Złomska M. Małachowski Piotr h. Nałęcz (ok. 1730-1799). W: PSB, t. 19. s. 409-411.

\title{
TEKLA MAŁACHOWSKA NEE WODZICKA AS A PROTECTOR OF THE CHARITY ASSOCIATION IN CRACOW. A CONTRIBUTION TO THE BIOGRAPHY
}

\begin{abstract}
The person I described in my article is Tekla Małachowska nee Wodzicka (1764-1829), daughter of Eliasz, a starost of Krakow, and Ludwika Wielopolska. Tekla was the second wife of Piotr Małachowski (1730-1799), the governor of Krakow province. After her husband's death, she settled in Stopnice near Krakow. She came back to public life during the period of the Duchy of Warsaw. Then she moved to Krakow and rendered services to the cause of organizing the Charity Association in Krakow. In February 1817 Małachowska became the first President of the Charity Association. She was taking care of the persons under the Charity Association's charge, organizing charitable concerts and balls where she assembled money for the Charity Association. Thanks to her personal qualities and welfare-and-social work Małachowska gained the general respect of community. Her friends were not only among the
\end{abstract}


representatives of aristocratic houses but also leading intellectualists of the time, such as Jan Śniadecki, who bequeathed 12 thousands Polish zlotys for education of children in Niedźwiedź. Tekla Małachowska died on 22 December 1829, and was buried with her husband in Niedźwiedź In token of gratitude for her protection, on 11 February 1821 the Charity Association resolved to hang the portraits painted on metal of Tekla Małachowska and Stanisław Mieroszewski in the Chapel of the Poor in the Wawel Castle. These portraits, stamped in copper, were distributed later among the members of the Charity Association. After Małachowska's death, a funeral mass for her soul was said on 16 January 1830 was. A few years later that sermon was recorded in the commemorative book/visitor's book of the deceased benefactors of the Charity Association in Cracow.

Key words: charity in Krakow, Tekla Wodzicka Małachowska, 